\title{
DYNAMICS OF DIGITAL TRANSFORMATIONS IN THE NATIONAL ECONOMY OF UKRAINE
}

\author{
Anatolii Pustovarov ${ }^{1}$
}

\begin{abstract}
The purpose of the paper is to analyse the quantitative changes dynamics in the development and application of information and communication technologies in production and sale of information, traditional goods and services, provision of public services, as well as in everyday life of citizens. Methodology. The main method of research is the trend analysis of statistical data provided on the official website of the State Statistics Service of Ukraine. Results of the survey showed dynamics of digital transformations in the information sector of national economy of Ukraine, the level of use of information and communication technologies by enterprises outside the information sector, as well as the population and government agencies (2016-2019). Practical implications. Positive and negative changes in the information sector because of digital transformations in national economy of Ukraine are found. There are positive changes: annual growth of the information sector; growth of production volumes with the use of medium-high technologies; increase in sales of services with computer equipment; level of use of fixed broadband Internet access by enterprises higher than the average; positive dynamics of Internet use by the population; availability of Internet access in $94 \%$ of surveyed government agencies. There are negative changes: reduction of indicators of the use of information and communication technologies at the enterprises outside information sector; insufficient provision of enterprises with specialists in information and communication technologies; a small number of companies with official website and cloud technology; low indicators of e-business development according to the B2B interaction model; lack of generally accepted methodology and list of evaluation indicators; unsatisfactory level of collection, grouping and provision of statistical data about dynamics of digital transformations of the national economy by the State Statistics Service of Ukraine; unsatisfactory level of use of e-democracy instruments. Value/originality. The findings can be used to improve the mechanisms and measures of state regulation of digitalization of the national economy.
\end{abstract}

Key words: digital transformations, information sector, information and communication services, website, cloud technologies, e-business, e-democracy instruments.

JEL Classification: E26, O33, O38

\section{Introduction}

The rapid development of current technologies has a positive impact on the development of national economies to achieve their Sustainable Development Goals. Nowadays, one of the main problems is to ensure the effective integration of the introduction of information and communication technologies (ICT) with the interests of key stakeholders in development processes: enterprises, individuals and government organizations. Timely identification of the shortcomings of such integration should be a priority for relevant government agencies and NGOs.

The use of digital technologies provides significant benefits: for companies - to increase productivity and competitiveness, for people - to acquire new knowledge and skills, job choices and opportunities, for governments - to improve the quality of public services to citizens and organizations. Countries are able to reap the full benefits of ICT transformation if they continually improve the business climate, invest in education and public health, and promote good governance. Countries that complement investment in new technologies with large-scale economic reforms receive digital dividends by accelerating economic growth, increasing jobs and improving the quality of services. Such reforms include improving the regulatory framework that allows organizations to use the Internet for competition and innovation, bringing employees up to the demands of new economy, enabling people to take full advantage of digital technologies, and ensuring accountability of institutions to ensure rapid needs and requirements of citizens.

\footnotetext{
Corresponding author:

${ }^{1}$ Zaporizhzhia City Council, Ukraine.

E-mail: ap.zp.gov@gmail.com

ORCID: https://orcid.org/0000-0002-7720-7689
} 
As digital transformation extends to all sectors and affects all aspects of society, measuring its individual characteristics and dynamics will become an increasingly difficult task to answer a wide range of questions, including how to measure and track digital transformations in all sectors of national economy, including the public sector; how to measure the destruction of existing business models and the emergence of new ones, the reorganization of the work or the size of the structural components of national economy; how to assess the value of data, both private and public, in standard statistics; how to track international transactions of digitized goods and services; how policies affect the digital economy and how to monitor and evaluate such impacts; what economic activities and jobs should appear in the future; what is the impact of digital transformations on the well-being of citizens and society as a whole.

Nowadays, information and communication technologies and digital transformation are the driver of technological change and a condition for national economy competitiveness and sustainable development. To increase the competitiveness of national economy, it is necessary to accelerate the start of digital transformation.

\section{Survey recent research}

The results, risks and benefits of ICT introduction in production and sale of traditional goods and services are surveyed by many Ukrainian and foreign researchers and scientists. The areas of such research are: analysis of the level of digitalization of Ukraine and the European Union (Karchev, Ohorodnia, Openko, 2017), analysis of the most famous indices to reflect level of digital transformation of national economies (Pizhuk, 2019; Yanenkova, 2017), selection of a group of indicators to analyse level of formation and development of digital economy (Semenog, 2020), development of methods to determine integrated indicators of condition and potential of digital development of the national economy (Kuzovkova, Salutina, Kukharenko, 2019), methods of calculating the International Digital Economy and Society Index (I-DESI, 2020), the Digital Economy and Society Index (DESI), the Network Readiness Index (2019).

However, currently there is no universal method of analysing these processes. The study of the dynamics of change on international indices does not always reflect the real transformations in a national economy. Therefore, we consider carrying out a trend analysis of the dynamics of digital transformations of the national economy. On the basis of statistical reporting, we should identify "bottlenecks" and positive changes in these processes.

\section{Methodology of digital transformations}

The study of the dynamics of digital transformations of the national economy requires defining the main components (parameters) and indices (indicators) of evaluation. There is currently no generally methodology and list of indicators. Thus, R. Kling and R. Lamb in their work (Kling, Lamb, 2000), based on the publication of L. Margherio et al. (Margherio, 1999), identified four main components of the digital economy: (1) digital products and services (access to information services, software sales, e-education, etc.); (2) mixed digital products and services (retail sale of real goods, hotel rooms, as well as related sales and marketing); (3) services and production of goods depended on information technology (accounting services, production of real goods, which require highprecision machining using software control, etc.); (4) products and services of the information sector (production of network equipment and personal computers, information consulting, etc.).

In "Measuring The U.S. Digital Economy: Theory and Practice", Thomas L. Mesenbourg and B. K. Atrostic (Mesenbourg, Atrostic, 2001) identified the following main components of digital economy: supporting infrastructure (hardware, software, telecommunications, networks), electronic business processes (characteristics of doing business), and e-commerce operations (sale of goods and services via the Internet).

Recently, the following international indices have become widespread and popular: the level of ICT development and use is determined by the Digital Economy and Society Index (DESI), the International Digital Economy and Society Index (I-DESI) (2020), and the Network Readiness Index (NRI) (2019), etc. The methodology for calculating the final indicator for each of these indices involves the selection of certain parameters and indicators of evaluation. The list of these parameters and indicators differs. The general evaluation parameters are: quality of fixed and mobile broadband communication, digital skills of the population, directions of the Internet use, development of sales channels via the Internet, digital government services.

To analyse the dynamics of digital transformations in the national economy of Ukraine, we use official statistical reporting and observations data of the State Statistics Service of Ukraine official website. It should be noted that most of the digital information on the level of ICT use is in "Information Society" section. However, data on the development of information sector of Ukrainian economy, the use and growth of the technologies market of varying complexity, the sale of goods and services using ICT are in "Activities of enterprises" section; data on exports and imports of services in telecommunications, computer and 
information services are in "Foreign economic activity" section; data on the use of the Internet by the population are on the website of the Internet Association of Ukraine in the section "Projects. Internet audience research."

The concept of "digital transformation" includes quantitative changes in the development and application of ICT in production of information and traditional goods and services, public services, as well as in the citizens' everyday life. Thus, the analysis of the dynamics of digital transformations involves identifying both positive and negative changes in functioning of information sector of the national economy, level of ICT use by enterprises, individuals and government agencies. The analysis uses 2016-2019 period according to the periodicity of updating statistical data on the official website of the State Statistics Service of Ukraine.

\section{Information sector in Ukraine}

The information sector of national economy consists of manufacturers of network equipment and personal computers, as well as firms that provide consulting services IT consulting. In 2016-2019, the number of enterprises operating in this sector (by $20 \%$ during the period), the number of employees of these enterprises (by $17.5 \%$ ) and the volume of products sold by them (twice) steady increased (Table 1).

The highest growth rate is for production using medium-high technologies $(+55 \%)$; the lowest one is for production using high technologies $(+30 \%)$. The latter includes: computer linguistics and computer science (formalization of problems and tasks that are similar to human actions (artificial intelligence)); data exchange between the physical world and computer systems using standard communication protocols (Internet of Things); merger of automated production, data exchange and production technologies into a single self-regulatory system with minimal or no human intervention (Industry 4.0); standalone devices; quantum computers; virtual reality, communication and $5 \mathrm{G}$ networks; blockchain, etc.

The reduction in the number of employees in enterprises that use high $(-7 \%)$, medium-high $(-2.6 \%)$ and medium-low production technologies $(-4.3 \%)$ is concerned (Table 2).

There are different reasons of reduction by various factors. The positive factors are increasing the share of automated work, optimization of business management processes, expanding the content of individual employees. The negative factors are unsatisfactory level

Table 1

Quantitative characteristics of the development of information sector of Ukraine in 2016-2019

\begin{tabular}{|l|c|c|c|c|c|}
\hline \multirow{2}{*}{\multicolumn{1}{|c|}{ Indicators }} & \multicolumn{4}{c|}{ Years } & Growth rate \\
\cline { 2 - 6 } & 2016 & 2017 & 2018 & $2016, \%$ \\
\hline Information sector & 4866 & 5272 & 5495 & 5848 & +20.2 \\
\hline number of enterprises, units & 50289 & 56838 & 57416 & 59102 & +17.5 \\
\hline number of employees, persons & 17980705 & 23187133 & 29024539 & 36118468 & +100.9 \\
\hline volume of sales, thousand UAH &
\end{tabular}

Source: Performance indicators of enterprises, State Statistics Service of Ukraine (2010-2019)

Table 2

The dynamics of using technologies of different levels of complexity in 2016-2019

\begin{tabular}{|c|c|c|c|c|c|}
\hline \multirow{2}{*}{ Indicators } & \multicolumn{4}{|c|}{ Years } & \multirow{2}{*}{$\begin{array}{c}\text { Growth rate } \\
2019 / 2016 \text {, \% }\end{array}$} \\
\hline & 2016 & 2017 & 2018 & 2019 & \\
\hline \multicolumn{6}{|c|}{ Production on high technologies using } \\
\hline number of enterprises, units & 916 & 961 & 1001 & 1040 & +13.5 \\
\hline number of employees, persons & 103351 & 103115 & 95706 & 95793 & -7.3 \\
\hline volume of sales, thousand UAH & 57556690 & 68846165 & 75731614 & 74890274 & +30.1 \\
\hline \multicolumn{6}{|c|}{ Production on medium-high technologies using } \\
\hline number of enterprises, units & 4895 & 5337 & 5647 & 5931 & +21.2 \\
\hline number of employees, persons & 356219 & 358760 & 360601 & 346833 & -2.6 \\
\hline volume of sales, thousand UAH & 183971302 & 214800925 & 265644383 & 285409769 & +55.1 \\
\hline \multicolumn{6}{|c|}{ Production on medium-low technologies using } \\
\hline number of enterprises, units & 12468 & 13485 & 14036 & 14799 & +18.7 \\
\hline number of employees, persons & 441371 & 432909 & 434703 & 422536 & -4.3 \\
\hline volume of sales, thousand UAH & 549233106 & 726062021 & 880188463 & 804372660 & +46.5 \\
\hline \multicolumn{6}{|c|}{ Production on low-level technologies using } \\
\hline number of enterprises, units & 14156 & 15414 & 16178 & 17005 & +20.1 \\
\hline number of employees, persons & 528683 & 550213 & 558281 & 547976 & +3.6 \\
\hline volume of sales, thousand UAH & 638848863 & 771463009 & 839602340 & 860556954 & +34.7 \\
\hline
\end{tabular}

Source: Performance indicators of enterprises, State Statistics Service of Ukraine (2010-2019) 
of wages, late payment of wages, unsatisfactory working conditions, and the use of imperfect management instruments. However, under the growth in sales staff reductions lead to an increase in productivity indicator, which is certainly a positive phenomenon.

\section{Dynamics of ICT}

The vast majority of ICT is used in services (97\% in 2019). The total growth of sales of services provided using ICT during the period is $76 \%$ (Table 3 ).

Simultaneously, the level of ICT use in goods production also has a positive trend under the growth of number of enterprises and sales.

In 2016-2019, there are the most significant quantitative changes in sales occurred in services related to the use of computer equipment (93.5\%), which include: computer programming services, development of the structure and content of the web-sites, development of the structure and content of databases, design and development of applications, configuration and implementation of the software application so that it operates within the information system of the client. Also, a significant increase $(71.2 \%)$ is in the volume of services using high technologies (Table 4).

The dynamics of indicators of ICT use at Ukrainian enterprises outside information sector is mostly negative in study period. Thus, number of enterprises used computers decreases in 7.2 p.p.; number of enterprises with Internet access decreases in 11.8 p.p.; the average number of employees who used computers with Internet access decreases in 50.7 p.p.; the number of enterprises using local computer networks, Intranet and Extranet decreases in 7.6, 4.4 and 0.7 p.p. respectively (Table 5).

The share of enterprises using fixed broadband Internet access in 2016-2019 is over 60\%. Simultaneously, there is an annual reduction of the indicator (Table 6).

The share of enterprises that has an official website ranges from 35.2 to $38.4 \%$ in 2016-2019. In 2019,

Table 3

The dynamics of using information and communication technologies in 2016-2019

\begin{tabular}{|c|c|c|c|c|c|}
\hline \multirow{2}{*}{ Indicators } & \multicolumn{4}{|c|}{ Years } & \multirow{2}{*}{$\begin{array}{c}\text { Growth rate } \\
2019 / 2016, \%\end{array}$} \\
\hline & 2016 & 2017 & 2018 & 2019 & \\
\hline \multicolumn{6}{|c|}{ Information and communication technologies } \\
\hline number of enterprises, units & 9979 & 11271 & 12291 & 13521 & +35.5 \\
\hline number of employees, persons & 132158 & 128973 & 127941 & 136485 & +3.3 \\
\hline volume of sales, thousand UAH & 150681907 & 188042533 & 230821579 & 261481025 & +73.5 \\
\hline \multicolumn{6}{|c|}{$\begin{array}{l}\text { in particular: } \\
\text { information and communication technologies in production }\end{array}$} \\
\hline number of enterprises, units & 286 & 285 & 293 & 320 & +11.9 \\
\hline number of employees, persons & 11004 & 10670 & 10341 & 10406 & -5.4 \\
\hline volume of sales, thousand UAH & 6349731 & 6637844 & 8588477 & 7497364 & +18.1 \\
\hline \multicolumn{6}{|c|}{ information and communication technologies in services } \\
\hline number of enterprises, units & 9693 & 10986 & 11998 & 13201 & +36.2 \\
\hline number of employees, persons & 121154 & 118303 & 117600 & 126079 & +4.1 \\
\hline volume of sales, thousand UAH & 144332172 & 181404689 & 222233103 & 253983661 & +76.0 \\
\hline
\end{tabular}

Source: Performance indicators of enterprises, State Statistics Service of Ukraine (2010-2019)

Table 4

The growth rate of the market for services using high technologies in 2016-2019

\begin{tabular}{|c|c|c|c|c|c|}
\hline \multirow{2}{*}{ Indicators } & \multicolumn{4}{|c|}{ Years } & \multirow{2}{*}{$\begin{array}{c}\text { Growth rate } \\
2019 / 2016, \%\end{array}$} \\
\hline & 2016 & 2017 & 2018 & 2019 & \\
\hline \multicolumn{6}{|l|}{ Services using high technologies } \\
\hline number of enterprises, units & 13244 & 14806 & 15859 & 17173 & +29.7 \\
\hline number of employees, persons & 260318 & 259184 & 255681 & 256276 & -1.6 \\
\hline volume of sales, thousand UAH & 127359909 & 150459570 & 185176262 & 218065820 & +71.2 \\
\hline \multicolumn{6}{|l|}{ Intellectually rich market services } \\
\hline number of enterprises, units & 64969 & 72331 & 77135 & 83254 & +28.1 \\
\hline number of employees, persons & 577084 & 563537 & 551099 & 604961 & +4.8 \\
\hline volume of sales, thousand UAH & 398904519 & 476283697 & 544879427 & 588633439 & +47.6 \\
\hline \multicolumn{6}{|l|}{ Services using computer equipment } \\
\hline number of enterprises, units & 5350 & 6264 & 7003 & 8063 & +50.7 \\
\hline number of employees, persons & 44939 & 47177 & 49533 & 58099 & +29.3 \\
\hline volume of sales, thousand UAH & 48660282 & 60826902 & 76545025 & 94175579 & +93.5 \\
\hline
\end{tabular}

Source: Performance indicators of enterprises, State Statistics Service of Ukraine (2010-2019) 
Table 5

The indicators of the use of information and communication technologies at the enterprises of Ukraine in 2016-2019

\begin{tabular}{|c|c|c|c|c|c|}
\hline \multirow{2}{*}{ Indicators } & \multicolumn{4}{|c|}{ Years } & \multirow{2}{*}{$\begin{array}{c}\text { Deviation } \\
\text { 2019/2016, p.p. }\end{array}$} \\
\hline & 2016 & 2017 & 2018 & 2019 & \\
\hline $\begin{array}{l}\text { Number of enterprises using computers, } \\
\text { in \% of total number of enterprises }\end{array}$ & 95.1 & 95.4 & 89.7 & 87.9 & -7.2 \\
\hline $\begin{array}{l}\text { Average number of employees who used } \\
\text { computers, in \% of total number of employees }\end{array}$ & 30.9 & 34.9 & 32.8 & 34.3 & +3.4 \\
\hline $\begin{array}{l}\text { Number of enterprises with Internet access, } \\
\text { in \% of total number of enterprises }\end{array}$ & 98.2 & 98.2 & 88.0 & 86.4 & -11.8 \\
\hline $\begin{array}{l}\text { Average number of employees who used } \\
\text { computers with Internet access, } \\
\text { in \% of total number of employees }\end{array}$ & 79.1 & 72.2 & 27.1 & 28.4 & -50.7 \\
\hline $\begin{array}{l}\text { Number of enterprises that: } \\
\text { uses a local area network (LAN),\% } \\
\text { has an Intranet,\% } \\
\text { has an Extranet,\% }\end{array}$ & $\begin{array}{c}59.5 \\
62.4 \\
8.8\end{array}$ & $\begin{array}{c}62.0 \\
67.0 \\
8.0\end{array}$ & $\begin{array}{c}53.5 \\
59.2 \\
8.3\end{array}$ & $\begin{array}{c}51.9 \\
58.0 \\
8.1\end{array}$ & $\begin{array}{l}-7.6 \\
-4.4 \\
-0.7\end{array}$ \\
\hline
\end{tabular}

Source: The use of information and communication technologies at enterprises, State Statistics Service of Ukraine (2016, 2017, 2018-2019)

Table 6

The number of enterprises using high-speed Internet access in 2016-2019

\begin{tabular}{|l|c|c|c|c|c|}
\hline \multirow{2}{*}{ Indicators } & \multicolumn{3}{c|}{ Years } & Deviation \\
\cline { 2 - 6 } & 2016 & 2017 & 2018 & 2019 & 2019/2016, p.p. \\
\hline Number of enterprises using narrowband access, \% & 31.3 & 32.9 & 31.4 & 30.6 & -0.7 \\
\hline Number of enterprises using fixed broadband access, \% & 67.1 & 66.3 & 62.1 & 60.9 & -6.2 \\
\hline Number of businesses using mobile broadband with portable devices, \% & 23.4 & 24.1 & 23.5 & 23.6 & +0.2 \\
\hline
\end{tabular}

Source: The use of information and communication technologies at enterprises, State Statistics Service of Ukraine (2016, 2017, 2018-2019)

Table 7

The main areas of use of websites by Ukrainian enterprises in 2016-2019

\begin{tabular}{|c|c|c|c|c|c|}
\hline \multirow{2}{*}{ Indicators } & \multicolumn{4}{|c|}{ Years } & \multirow{2}{*}{$\begin{array}{c}\text { Deviation } \\
\text { 2019/2016, p.p. }\end{array}$} \\
\hline & 2016 & 2017 & 2018 & 2019 & \\
\hline $\begin{array}{l}\text { Number of enterprises with website, in } \% \text { of total number of } \\
\text { enterprises, in particular the website provided an opportunity: }\end{array}$ & 37.5 & 38.4 & 35.6 & 35.2 & -2.3 \\
\hline customer service & 17.3 & 17.6 & 16.9 & 16.7 & -0.6 \\
\hline product supply & 6.2 & 6.6 & 6.3 & 6.1 & -0.1 \\
\hline order goods and services online & 10.2 & 10.5 & 10.3 & 10.2 & 0 \\
\hline links to company profiles on social media & 14.8 & 16.2 & 16.2 & 16.5 & +1.7 \\
\hline providing information on open vacancies & 10.0 & 10.8 & 10.5 & 10.4 & +0.4 \\
\hline personnel training & 3.6 & 3.8 & 3.9 & 3.9 & +0.3 \\
\hline
\end{tabular}

Source: The use of information and communication technologies at enterprises, State Statistics Service of Ukraine (2016, 2017, 2018-2019)

the indicator decreases in 2.3 p.p. compared to one in 2016. The most common website options are customer service and links to company profiles on social networks, the least common - staff training (Table 7). Fluctuations in the relative use of websites can be considered insignificant.

The use of cloud technologies can be considered insufficient: only $8.8-10.3 \%$ of enterprises purchase the relevant services. There are reasons for the slow spread of cloud technologies: problems with secure transmission and storage of data, the need for a constant connection to the Internet, the risk of information loss. However, the indicator has a positive trend (Table 8).
Indicators of e-business development by the "B2B" interaction model are insignificant. Thus, the share of enterprises purchasing goods or services via the Internet ranges from 17.2 to $20.3 \%$ (Table 9). The overall dynamics of the indicator is positive but insignificant one (an increase of 2.9 p.p.).

The share of enterprises receiving orders via the Internet for the sale of goods or services ranges from 4.8 to $6.4 \%$ and decreases over the period by 1.2 p.p. The largest share of products sold through websites or applications is $4.5 \%$ of total sales of enterprises. It is considered a very low figure.

The dynamics of indicators of the Internet use by the population in 2016-2019 is insignificant, but 
Table 8

The dynamics of use of cloud technologies by Ukrainian enterprises in 2016-2019

\begin{tabular}{|c|c|c|c|c|c|}
\hline \multirow{2}{*}{ Indicators } & \multicolumn{4}{|c|}{ Years } & \multirow{2}{*}{$\begin{array}{c}\text { Deviation } \\
\text { 2019/2016, p.p }\end{array}$} \\
\hline & 2016 & 2017 & 2018 & 2019 & \\
\hline $\begin{array}{l}\text { Number of enterprises that purchases cloud computing } \\
\text { services, in \% of total number of enterprises }\end{array}$ & 8.8 & 9.8 & 9.8 & 10.3 & +1.5 \\
\hline $\begin{array}{l}\text { Number of enterprises that analyses the "big data" } \\
\text { from smart devices or sensors, } \%\end{array}$ & 8.6 & 7.6 & 5.9 & 5.7 & -2.9 \\
\hline $\begin{array}{l}\text { The number of companies that analyses the "big data" } \\
\text { from portable geolocation devices, } \%\end{array}$ & 3.5 & 3.7 & 3.4 & 3.7 & +0.2 \\
\hline $\begin{array}{l}\text { Number of enterprises that analyses the "big data" } \\
\text { from social media, } \%\end{array}$ & 4.1 & 3.9 & 3.3 & 3.3 & -0.8 \\
\hline
\end{tabular}

Source: The use of information and communication technologies at enterprises, State Statistics Service of Ukraine (2016, 2017, 2018-2019)

Table 9

The dynamics of e-business development in Ukraine in 2016-2019

\begin{tabular}{|l|c|c|c|c|c|}
\hline \multicolumn{1}{|c|}{ Indicators } & \multicolumn{2}{c|}{ Years } & $\begin{array}{c}\text { Deviation } \\
\text { 2019/2016, p.p. }\end{array}$ \\
\cline { 2 - 5 } & 2016 & 2017 & 2018 & 2019 & +2.9 \\
\hline $\begin{array}{l}\text { Number of enterprises purchasing goods or services via } \\
\text { the Internet, in \% of total number of enterprises }\end{array}$ & 17.2 & 20.3 & 19.5 & 20.1 & -1.2 \\
\hline $\begin{array}{l}\text { Number of enterprises receiving orders via the Internet } \\
\text { for the sale of goods or services, in \% of total number of enterprises }\end{array}$ & 6.0 & 6.4 & 50 & 4.8 & \\
\hline $\begin{array}{l}\text { Volume of sold products (goods, services) receiving from trade } \\
\text { through websites or applications (applications), in \% to total } \\
\text { volume of sold products (goods, services) of enterprises }\end{array}$ & $\ldots$ & $\ldots$ & 3.5 & 4.5 & - \\
\hline
\end{tabular}

Source: The use of information and communication technologies at enterprises, State Statistics Service of Ukraine (2016, 2017, 2018-2019)

positive one (Table 10). The highest growth rate in 2019 is the number of regular Internet users (7 p.p.). Simultaneously, mobile phones or smartphones and home laptops are mostly used as technical devices by regular users to access the network. Residents of cities with a population of less than 100,000 in 2019 account for $29 \%$ of total number of Internet users. The same share falls on rural residents.

The distribution of network users by regions of the country in 2019 is: the Central-Northern regions of Ukraine - 33\%, the Eastern regions - 29\%, the Western regions $-27 \%$, the Southern regions $-11 \%$. The most numerous age groups among Internet users are people aged 25-34 years (25\%) and aged $35-44$ years $(21 \%)$.

\section{E-democracy instruments}

The analysis of the dynamics of indicators of the use of e-democracy instruments by public authorities and local governments due to the lack of data for the study period is impossible. The website of the State Statistics Service of Ukraine shows the results of the survey for 2019 only. They show that more than $94 \%$ of surveyed government agencies have Internet access and only about $22 \%$ of them provides citizens with e-democracy instruments such as "E-appeal", "E-petition", "E-consultation", "Participation budget (public budget)" (Table 11).

Since 2018, the Center for Innovation Development conducts a study of the Local e-Democracy Index on the following indicators: democratic regulations,

Table 10

The dynamics of indicators of the Internet use by population in 2016-2019

\begin{tabular}{|c|c|c|c|c|c|}
\hline \multirow{2}{*}{ Indicators } & \multicolumn{4}{|c|}{ Years } & \multirow{2}{*}{$\begin{array}{c}\text { Deviation } \\
\text { 2019/2016, p.p }\end{array}$} \\
\hline & 2016 & 2017 & 2018 & 2019 & \\
\hline Availability of Internet at home & 61.3 & 63.4 & 65.0 & 65.0 & +4.7 \\
\hline Share of regular users & 64.0 & 64.1 & 63.0 & 71.0 & +7.0 \\
\hline $\begin{array}{l}\text { Internet penetration by types of settlements: } \\
\text { cities with a population of } 100 \text { thous.+ }\end{array}$ & 71.0 & 77.0 & 71.0 & 74.0 & +3.0 \\
\hline cities with a population of 100 thous. - & 66.0 & 67.0 & 63.0 & 70.0 & +4.0 \\
\hline villages & 54.0 & 53.0 & 53.0 & 58.0 & +4.0 \\
\hline
\end{tabular}

Source: Internet Audience Research 
Table 11

The indicators of the use of e-democracy instruments in 2019

\begin{tabular}{|l|c|c|c|c|c|}
\hline \multicolumn{1}{|c|}{ Indicators } & \multirow{4}{*}{ Total } & $\begin{array}{c}\text { Of them } \\
\text { public } \\
\text { authorities }\end{array}$ & $\begin{array}{c}\text { bodies of } \\
\text { judicial } \\
\text { system }\end{array}$ & $\begin{array}{c}\text { local } \\
\text { governments }\end{array}$ & $\begin{array}{c}\text { state organizations } \\
\text { (institutions, } \\
\text { establishments) }\end{array}$ \\
\hline Number of institutions with the Internet access, units & 17678 & 5102 & 695 & 10584 & 1297 \\
\hline $\begin{array}{l}\text { Share of institutions with Internet access } \\
\text { in total number of institutions of survey, \% }\end{array}$ & 94.7 & 92.5 & 87.9 & 96.6 & 92.8 \\
\hline $\begin{array}{l}\text { Number of institutions providing the opportunity } \\
\text { to use of e-democracy instruments, units }\end{array}$ & 3853 & 1326 & 568 & 1818 & 141 \\
\hline in\% to total number of institutions with Internet access & 21.8 & 26.0 & 81.7 & 17.2 & 10.9 \\
\hline
\end{tabular}

Source: Use of E-democracy instruments by Public authorities and Local governments (2019)

availability of IT instruments, number and percentage of unique active users, number of created cases, number of considered cases, number of supported cases, number of completed cases, percentage of completed cases, duration of execution. In 2017, the top three cities includes Kyiv, Khmelnytsky and Vinnytsia (Prykhodko, Yemelianova, Loboiko, Khutkyi, Kushnirenko, 2018), in 2018 the leaders are Kyiv, Ivano-Frankivsk and Lviv (Yemelianova, Loboiko, Maievska, 2019).

On the surveys and measurements, the authors of the reports identify the following shortcomings in the use of e-democracy instruments: inaccessibility to platform administrators from the local government of statistical indicators on attendance, number of registered users, etc.; lack of information from local governments on the effectiveness of e-petitions and e-consultations made it impossible to consider them in local policies; closeness of e-democracy instruments for cooperation with IT volunteers and further improvement.

\section{Conclusions}

The analysis of the dynamics of digital transformations of national economy of Ukraine in 2016-2019 reveals the positive changes as: annual growth of the information sector, growth of production using medium-high technologies, significant quantitative changes in sales of services related to computer equipment; the share of enterprises using fixed broadband Internet access is over $60 \%$; positive dynamics of Internet use by the population, availability of the Internet in $65 \%$ of households, growth in the share of regular network users; availability of Internet access in $94 \%$ of surveyed government agencies.

There are some negative changes: reduction of information and communication technologies in enterprises outside information sector; low level of enterprises with an official website and cloud technologies; insignificant indicators of e-business development according to the "B2B" interaction model; a low share of public institutions providing citizens with the opportunity to use the e-democracy instruments. Also, the negative aspects of the analysis of the dynamics of digital transformations are: the lack of a common methodology and list of evaluation indicators; unsatisfactory level of collection, grouping and provision by the State Statistics Service of Ukraine of statistical data characterizing the dynamics of digital transformations of the national economy.

The further researches include techniques and means to improve the state regulation of digitalization of national economy.

\section{References:}

DESI 2020: How digital is Europe compared to other major world economies? Available at: https:/ / ec.europa.eu/digital-single-market/en/news/i-desi-2020-how-digital-europe-compared-other-majorworld-economies (accessed 02 November 2020).

Digital Agenda Key Indicators. Available at: https://digital-agenda-data.eu/datasets/digital_agenda_scoreboard_ key_indicators (accessed 02 November 2020).

Internet audience research. Available at: https://inau.ua/proekty/doslidzhennya-internet-audytoriyi (accessed 02 November 2020).

Karcheva, H. T., Ohorodnia, D. V., \& Openko, V. A. (2017). Digital economy and its impact on the development of national and international economy. Financial space, no. 3(27), pp. 13-21. (in Ukrainian)

Kling, R., \& Lamb, R. (2000). IT and Organizational Change in Digital Economies. Understanding the Digital Economy (E. Brynjolfsson, B. Kahin (eds)). Cambridge: MIT Press, MA, pp. 295-324.

Kuzovkova, T. A., Salutina, T. Yu., \& Kukharenko, E. G. (2019). Methodological foundations and results of an integral assessment of digital development of economy and society. Electronic scientific journal "Age of Quality", no. 3, pp. 106-122. Available at: http://www.agequal.ru/pdf/2019/319007.pdf (accessed 02 November 2020). (in Ukrainian) 
Margherio, L. et al. (1999). The Emerging Digital Economy. Washington, DC: Department of Commerce. Available at: http://www.esa.doc.gov/sites/default/files/emergingdig_0.pdf (accessed 02 November 2020). NRI 2019 Analysis. The Redesigned NRI Model. Available at: https://networkreadinessindex.org/2019/nri-2019analysis/\#renewed-model (accessed 02 November 2020).

OECD. Classification of manufacturing industries into categories based on R\&D intensities/2011/. Available at: https://www.oecd.org/sti/ind/48350231.pdf (accessed 02 November 2020).

Performance indicators of enterprises grouped by special aggregations (2010-2019). Available at: https://ukrstat.org/uk/operativ/menu/menu_u/sze_20.htm (accessed 02 November 2020).

Pizhuk, O. I. (2019). Modern methodological approaches to assessing the level of digital transformation of the economy. BUSINESS INFORM, no. 7, pp. 39-47. Available at: https://www.business-inform.net/export_pdf/ business-inform-2019-7_0-pages-39_47.pdf (accessed 02 November 2020). (in Ukrainian)

Prykhodko, Kh., Yemelianova, A., Loboiko, S., Khutkyi, D., \& Kushnirenko, T. (2018). Indeks mistsevoi elektronnoi demokratii v Ukraini: pilotne doslidzhennia [The Local Electronic Democracy Index in Ukraine: A Pilot Study]. Kyiv: Innovation Development Center. Available at: https://cid.center/wp-content/uploads/2019/09/E-DemIndex-2018.pdf (accessed 02 November 2020). (in Ukrainian)

Semenog, A. Yu. (2020). Analysis of world ratings for formation and development of digital economy and Ukraine's place. Scientific Bulletin of the International Humanities University. Series: Economics and Management, vol. 43, pp. 38-43. DOI: https://doi.org/10.32841/2413-2675/2020-43-6. Available at: http://www.vestnik-econom. mgu.od.ua/journal/2020/43-2020/8.pdf (accessed 02 November 2020). (in Ukrainian)

The use of e-democracy instruments by public authorities and local governments in 2019. Available at: http://www.ukrstat.gov.ua/ (accessed 02 November 2020).

The use of information and communication technologies at enterprises in 2018-2019. Available at: https://ukrstat.org/uk/operativ/operativ2018/zv/ikt/arh_ikt_u.html (accessed 02 November 2020).

The use of information and communication technologies at enterprises in 2017. Available at: https://ukrstat.org/ uk/operativ/operativ2018/zv/ikt/arh_ikt_u.html (accessed 02 November 2020).

The use of information and communication technologies at enterprises of Ukraine in 2016. Available at: https://ukrstat.org/uk/druk/publicat/kat_u/publinform_u.htm (accessed 02 November 2020).

The volume of services sales in telecommunications and postal services field. Available at: http://www.ukrstat.gov.ua/ (accessed 02 November 2020).

Thomas, L. Mesenbourg, B. K. Atrostic Measuring The U.S. Digital Economy: Theory and Practice. Available at: https://2001.isiproceedings.org/pdf/1074.PDF (accessed 02 November 2020).

Yanenkova, I. H. (2017). Digital transformation of Ukrainian industry: key highlights. Problems economy, no. 4, pp. 179-184. Available at: https://www.problecon.com/export_pdf/problems-of-economy-2017-4_0pages-179_184.pdf (accessed 02 November 2020). (in Ukrainian)

Yemelianova, A., Loboiko, S., \& Maievska, O. (2019). Indeks mistsevoi elektronnoi demokratii v Ukraini [The Local e-democracy Index in Ukraine]. Kyiv: Innovation Development Center. Available at: https://cid.center/ wp-content/uploads/2019/12/e-dem-index-2.0.pdf (accessed 02 November 2020). (in Ukrainian) 